\title{
A Proposal for the Abolition of the Incompetency Plea
}

\author{
Robert A. Burt \\ Norval Morris $\ddagger$
}

Though neither convicted of a crime nor civilly committed, many incompetent criminal defendants have been, in effect, serving life terms in state mental hospitals. ${ }^{1}$ A study of Massachusetts practice found, for example, that of all incompetent defendants committed to Bridgewater, the relevant state institution, "more . . . had left by dying than by all other avenues combined." In Jackson $v$. Indiana, ${ }^{3}$ a unanimous Supreme Court ended the common practice of committing for an indeterminate time persons accused of crime but found incompetent to stand trial. ${ }^{4}$ Jackson held that an incompetency commitment cannot last

$\dagger$ Professor of Law, University of Michigan.

$\ddagger$ Julius Kreeger Professor of Law and Criminology, The University of Chicago.

We have been ably assisted in this article by Robert Berger and Jean Camp, students at The University of Chicago Law School, and Margaret Fraser, a student at the University of Michigan Law School. Their research was supported by The Center for Studies in Criminal Justice at The University of Chicago.

1 The number of criminal defendants tangled in the incompetency web is substantial. In 1967, for example, more than half of all persons who were committed to state mental institutions when accused or convicted of crimes were committed as incompetent to stand trial; 38 percent $(4,282)$ of the total were committed for competency determinations and an additional 14 percent $(1,527)$ were committed as incompetents. By contrast, successful invocation of the insanity defense accounted for only 4 percent (409) of all criminal offenders in state mental institutions in 1967. The remaining 44 percent $(4,991)$ were convicted criminals transferred from prison to mental institutions due to "mental illness." P. Scheidemander \& C. Kanno, The Mentally Ill Offender 20 (1969).

2 McGarry, The Fate of Psychotic Offenders Referred for Trial, 127 AM. J. Psychiatry 1181 (1971); see A. Matthews, Mental Disability and the Criminal LaW 138 (1970).

3406 U.S. 715 (1972).

4 Jackson invalidates the laws permitting indeterminate incompetency commitments in almost every state in the country. See, e.g., ALA. CoDE \& 15.426 (1959); 17 ARIz. REv. STAT. ANN. § XV-250(B) (1956); CAL. PENAL CODE §§ 1370-71 (1972); GA. CODE ANN. § 27-1504 (1972); IND. ANN. STAT. § 9-1706a(2) (Supp. 1972) (now codified as IND. CodE of 1971, § 355-3-2(2)); Minn. Stat. ANN. \& 631.18 (Supp. 1972); Mo. ANn. Stat. § 552.020(7) (Supp. 1971); Mont. REv. Codes ANN. \& 95-506(b) (1969); Nev. Rev. Stat. § 178.425 (1967); N.C. Gen. Stat. § 122-83 (Supp. 1971); N.D. CENT. Code § 29-20-02 (Supp. 1971); Oho Rev. Code ANn. \$ 2945.38 (1954); Utah Code ANN. \& 77-48-5 (Supp. 1971); Wis. Stat. ANN. $\S 957.13$ (1958). Most jurisdictions automatically commit all defendants found incompetent to stand trial; a few states commit only those who are also found "dangerous." See 18 U.S.C. $\$ 4247$, interpreted in Maurietta v. Ciccone, 305 F. Supp. 775 (W.D. Mo. 1969); IowA 
longer "than the reasonable period of time necessary to determine whether there is a substantial probability that [an incompetent criminal defendant will become competent] . . . in the foreseeable future" and that "continued commitment must be justified by progress toward that goal." 5

States will likely be tempted, in the wake of Jackson, to resort to civil commitment proceedings rather than dismiss charges against and release permanently incompetent defendants. It is the thesis of this article, however, that the interests of both permanently incompetent defendants and the states would be better served by abandonment of the traditional rule against trying incompetent defendants. Incompetency should instead be grounds for obtaining a trial continuance during which the state must provide resources to assist the defendant toward greater trial competence. If trial competence is not achieved within six months, the state should be required to dismiss charges or proceed to a trial governed, where necessary, by procedures designed to compensate for the incompetent defendant's trial disabilities. Proposed rules of court for the granting of trial continuances and the conduct of an incompetent's trial are set forth in the Appendix to this article.

\section{Jackson v. Indiana}

The facts in Jackson starkly presented the plight of incompetent criminal defendants to the Court. In 1968, when he was twenty-seven, Theon Jackson was arrested for two purse-snatchings involving $\$ 9.00$. (Whether any violence was alleged to have accompanied these robberies is not clear from the record.) Jackson was a deaf-mute with virtually no capacity to communicate: he could neither read, write, nor use sign language. An attorney was appointed for Jackson and, as required by

Code § 783.3 (Supp. 1972); OKLA. Stat. ANN. § 22-1167 (Supp. 1972); S.D. Compiled Laws ANN. \& 23-38-6 (1967).

A few jurisdictions do impose some time limit on incompetency commitments. The federal commitment statute has been interpreted to require that a defendant who will clearly never become competent be "transferred [from the federal psychiatric facility at Springfield, Mo.] to the appropriate state authorities" for civil commitment proceedings. Cook v. Ciccone, 312 F. Supp. 822, 824 (W.D. Mo. 1970). See also Maurietta v. Ciccone, supra; Martin v. Settle, 192 F. Supp. 156 (W.D. Mo. 1961). New York has recently adopted a statute imposing maximum time limits on commitments for incompetent felony defendants and requiring dismissal of any indictment for incompetent misdemeanor defendants who are civilly committed. N.Y. Code Crim. Proc. $\S \S 730.50(1)$, (3) (1971); cf. text at note 43 infra. See also ConN. Gen. Star. AnN. § 54-40(d) (Supp. 1972). For Michigan and Illinois practices imposing limits on incompetency commitments, see note 19 and text and note at note 57 infra, respectively.

5406 U.S. at 738. 
Indiana law, the trial court selected two psychiatrists to consider his competency to stand trial. At a subsequent competency hearing, the psychiatrists filed a joint report concluding that Jackson was mentally retarded-his diagnosed "moderately severe mental deficiency" was interpreted by the Supreme Court to mean that he had the "mental level of a pre-school child" - and that his "almost nonexistent communication skill ... left him unable to understand the nature of the charges against him or to participate in his defense." Both psychiatrists testified that Jackson was unlikely ever to become competent to stand trial. The state school for the deaf did not accept the "mentally retarded deaf," and there were no other state facilities that could offer any treatment opportunities to Jackson, even if he had the capacity to benefit from them. The trial court found Jackson incompetent to stand trial and, notwithstanding the dreary prospects outlined at the hearing, committed him to the custody of the state Department of Mental Health until it could certify that he was competent to stand trial.

The manifest injustice of Jackson's commitment, which the Supreme Court saw as a life sentence for a permanently incompetent defendant, ${ }^{8}$ led the Court unanimously to overturn the commitment. The Court provided two grounds for its decision. First, it ruled that Jackson had been denied equal protection because the state withheld from him advantages that it gave to civilly committed persons. Second, the Court ruled that Jackson had been denied due process because his commitment had no "reasonable relation to the purpose for which" the state purported to commit him-to make him competent to stand trial.

The Court's equal protection reasoning appears to have been based on an essential similarity between Jackson's incompetency commitment and civil commitment: Jackson, like a person civilly committed, had been involuntarily placed in state custody for an indeterminate period because he exhibited some mental illness or mental disability. Indeterminate commitment on the basis of mental disability alone has been increasingly opposed by the Court since its ruling in Baxstrom $v$. Herold $^{9}$ that a convicted criminal cannot be shifted into indeterminate mental hospitalization at the end of his penal sentence without benefit

6 Id. at 717.

7 Id. at 718. This formulation is the essential substantive standard for competency to stand trial in every jurisdiction. See Dusky v. United States, 362 U.S. 402 (1960).

8 "There is nothing in the record," the Court found, "that even points to any possibility that Jackson's present condition can be remedied at any future time." 406 U.S. at 726 .

9383 U.S. 107 (1966); see McNeil v. Director, Patuxent Institution, 407 U.S. 245 (1972); Humphrey v. Cady, 405 U.S. 504 (1972). 
of the same standards and procedural protections that apply to civil commitments.

The Court's adherence to the Baxstrom principle has significant implications, both good and bad, for the rights of mentally disabled criminal offenders. For the good, the Court is standing firm against any easy imposition of a hybrid status-"mad and bad"-that states have used in many contexts to justify longer and more onerous incarcerations for the "criminally insane" than they impose either for criminals or for the insane. ${ }^{10}$ Theon Jackson, for example, could not have been imprisoned as a criminal since he was never criminally tried. He could not have been committed for mental illness, since the required demonstrations of illness and consequent need for "treatment" or "detention" for community or self-protection had not been made.11 He could not have been committed as a "feeble-minded person" under Indiana law without a showing that he was "unable properly to care for [himself],"12 a possibility discussed below. Yet, notwithstanding the fact that state law did not authorize criminal or civil commitment, Jackson's unlucky

10 See text and notes at notes $46-49$ infra. Among those who suffer from this hybrid status are criminal defendants found not guilty by reason of insanity, persons committed under "dangerous sexual psychopath" laws and persons committed under "defective delinquent" laws. The Supreme Court has ruled that indeterminate extension of a sex offender's prison sentence based on "mental illness," and indeterminate diagnostic commitment of a suspected "defective delinquent" violate the Baxstrom principle. See McNeil v. Director, Patuxent Institution, 407 U.S. 245 (1972); Humphrey v. Cady, 405 U.S. 504 (1972). Lower courts have read Baxstrom to require that ordinary civil commitment proceedings be conducted in order to authorize indeterminate commitment of a defendant found not guilty by reason of insanity. Bolton v. Harris, 395 F.2d 642 (D.C. Cir. 1968); People v. Lally, 19 N.Y.2d 27, 224 N.E.2d 87 (1966). See also Specht v. Patterson, 386 U.S. 605 (1967); United States ex rel. Schuster v. Herold, 410 F.2d 1071, 1081 (2d Cir. 1969). For a pre-Baxstrom statement of the problem, see N. Morris, Psychiatry and the Dangerous Criminal, 41 S. CAx. L. REv. 514, 525 (1968):

The police power and the mental health power are surely sufficient separately to control questions of dangerousness and the maxima of state power over individual citizens. It is a mutually corruptive, potent source of injustice loosely and thoughtlessly to blend these two powers, and thus to gloss over in each the proper balance between state power and the freedom of the individual. Common to both powers is the concept of social dangerousness. The problem for both prison authorities and mental health authorities is reasonably and effectively to assess social dangerousness and to design processes by which these assessments can reasonably be fed into the releasing procedure. This task is not facilitated by making a porridge, a farrago, out of the mental health power and the police power and using this mess to avoid facing this genuinely difficult problem and trying to dispose of it.

11 IND. ANn. STAT. § 22-1201/1) (Supp. 1972) (now codified as IND. Code of 1971, \& 16-14-9-1(1)) defines a "mentally ill person" as one who "is afflicted with a psychiatric disorder which substantially impairs his mental health; and, because of such psychiatric disorder, requires care, treatment, training or detention in the interest of the welfare of such person or the welfare of others of the community in which such person resides."

12 IND. ANN. STAT. \& 22-1907, 22-1801 (1964) (now codified as IND. CoDE of 1971, $\S \S 16-15-1-8,16-15-4-1)$, construed in Jackson v. Indiana, 406 U.S. at 721 n.3. 
conjunction of mental disability and threshold involvement in the state's criminal justice system had brought him indeterminate mental hospitalization.

By following Baxstrom, the Court implicitly asked the right questions: If the criminal charge alone or the mental disability alone would not have justified Jackson's indeterminate commitment, why should these factors together have done so? Was Jackson more dangerous than other accused criminals simply because he was incompetent to stand trial? Did he need psychiatric care more than the "mentally ill" or "feeble-minded" simply because he had been accused of a crime? The Baxstrom principle, as applied in Jackson, forces precise identification and justification of the purposes served by state mental health commitment laws. It is an invaluable analytic technique with which to begin disentangling the overlapping, contradictory, and often unacknowledged purposes of the mental health and criminal law powers.

Despite these virtues, the Baxstrom principle also has potential for harm. If equal protection analysis requires equal treatment for the "insane" and the "criminally insane," then states may well be drawn to greater abuse of the mad in order to be sure of ensnaring the bad. Theon Jackson's situation, further considered, well illustrates this danger. No one had suggested that he was "mentally ill"; even the diagnosis of his mental retardation is suspect insofar as it suggested organic intellectual impairment. ${ }^{13}$ The severity of Jackson's disabilities is quite plausibly linked to his past history: he is black, born deaf in rural Mississippi and, until he and his family moved to Indiana when he was twenty-four, had never attended a school of any kind:14 he was employed at the time of his arrest and had no prior history of institutionalization or arrest.

On this record, as the Supreme Court noted, ${ }^{15}$ no Indiana law would appear to authorize Jackson's civil commitment. At the same time, however, the Indiana law governing commitment of the "feebleminded" does not clearly preclude his commitment. The Supreme Court construed that law to require a finding that the "feeble-minded" person was "unable properly to care for himself." This imprecise formulation, like that found in most civil commitment statutes, leaves ample opportunity for the state to incarcerate unpleasant people.

13 See R. Heber, a manual on Terminology and Classification in Mental RetardaTION 10-12 (1961).

14 He had recently attended some classes but his progress in attaining communications skills was exceedingly limited. See 406 U.S. at 726; Petition for Certiorari at 21 (app.), Jackson v. Indiana, 406 U.S. 715 (1972).

15406 U.S. at 728. 
Jackson is clearly vulnerable. ${ }^{10}$ His vulnerability to civil commitment appears to have been greatly increased by the Supreme Court's ruling that he can no longer be confined solely because he is incompetent to stand trial. If state officials cannot bring to trial an incompetent person whom they believe to be a criminal, and cannot hold him simply because he is incompetent, it is far from unlikely that the civil commitment statute will be stretched to fit his case.

Most civil commitment statutes lend themselves readily to this purpose: substantive standards are vague; fact-finding processes are haphazard; and no effective time limits on commitment are assured. ${ }^{17}$ While reform efforts ${ }^{18}$ have had useful impact in some states, Jackson invites the states to preserve the worst elements of their civil commitment laws in order to confine the "criminally insane" who, under the BaxstromJackson principle, can no longer be indefinitely confined as incompetent. ${ }^{19}$

The Supreme Court indirectly addressed this danger in its discussion of the due process ground for its holding in Jackson. "At the least," the Court said, "due process requires that the nature and duration of commitment bear some reasonable relation to the purpose for which the individual is committed."20 Since Jackson was committed because he was incompetent to stand trial, the Court concluded that the purpose of such commitment must be to make the defendant competent.21

16 Indeed, Jackson's appointed counsel argued that criminal charges should have been dismissed and Jackson committed as a "feeble-minded person." Brief for Petitioner at 17, Jackson v. Indiana, 406 U.S. 721 (1972).

17 See generally F. Muller, R. Dawson, G. Dix \& R. Parnas, The Mentat Health Process 1507-1627 (1971).

18 See, e.g., California Mental Health Act (Lanterman-Petris-Short Act), CAL. WeLf. \& INST'Ns CoDE §§ 5355 et seq. (West 1972).

10 Consider the "reform" enacted by Michigan in 1966. In response to criticism of indeterminate incompetency commitments, an eighteen-month maximum was set. Mrch. Comp. LAws \& 767.27a(7) (1972). If the criminal defendant has not become competent to stand trial at the end of this time, civil commitment proceedings are commenced. Id. If, however, the court refuses to commit the defendant civilly, he is referred to the criminal court that originally found him incompetent; "If the original committing court determines that the defendant is still incompetent to stand trial ... the decision of the [civil commitment court] is reversed and ... the defendant [is immediately committed] to the department of mental health for treatment in an appropriate state hospital." Id. at $\S 767.27 \mathrm{a}(8)$. Jackson invalidates this scheme, but legislatures can be expected to seek the same result with different formal trappings.

20406 U.S. at 738.

21 There are, of course, other possible purposes-most notably, to stow away an awkward, troublesome, and possibly dangerous citizen in order to "protect" the community. See Lewin, Incompetency to Stand Trial: Legal and Ethical Aspects of an Abused Doctrine, 1969 LAw \& SOCIAL ORDER 233, 283-84, 284 n.146. The Court properly chose not to recognize this purpose, and, of course, the state did not directly admit so unat- 
The Court's due process reasoning, applied equally to all civil commitments as its language suggests, would assure that "the nature and duration" of those commitments "bear some reasonable relation to [a legitimate state] purpose." In effect, the Supreme Court has endorsed the doctrinal foundation that several lower courts have articulated to support a constitutional "right to treatment" whenever detention purports to be based on a need for treatment. ${ }^{22}$ Indeed, the Court explicitly invited litigation to test the relation between the asserted purposes and actual uses of civil commitments. ${ }^{23}$ It seems likely, therefore, that the Court is willing to confront directly any misuses of the civil commitment power that its stringent application of the Baxstrom principle to incompetents may bring about.

The problems created by misusing civil commitment laws to ensnare permanently incompetent criminal defendants would not be adequately resolved by requiring that civil commitment proceedings, like juvenile court proceedings following Gault, ${ }^{24}$ closely approximate criminal trials. That course might better protect incompetent defendants, but if civil commitment reforms went no further they would not provide adequate protection to all of the others subject to civil commitment laws. For this larger group, there can be no adequate protection until civil commitments cease to be indeterminate. This result is the ultimate implication of the Baxstrom-Jackson principle, that any differences between indeterminate civil commitment of the "dangerous mentally ill" and criminal confinement of the "dangerous" must be justified. Yet no differences between these statuses can be justified. Our predictive tools are so uncertain, and the curative promises of long-term confinement are so hollow, that the "dangerous mentally ill" are indistinguishable from the "criminally dangerous." Both groups must, therefore, be treated alike before long-term confinement can be imposed upon either. ${ }^{25}$

tractive a motive for committing Jackson, as it would not to justify civil commitments generally.

22 See Rouse v. Cameron, 373 F.2d 451 (D.C. Cir. 1966); Wyatt v Stickney, 325 F. Supp. 781 (M.D. Ala. 1971); cf. Creek v. Stone, 379 F.2d 106 (D.C. Cir. 1967) (dictum) (commitment to juvenile home).

23406 U.S. at 737: "The States have traditionally exercised broad power to commit persons found to be mentally ill. . . . The bases that have been articúlated include dangerousness to self, dangerousness to others, and the need for care or treatment or training. Considering the number of persons affected, it is perhaps remarkable that the substantive constitutional limitations on this power have not been more frequently litigated." (footnotes omitted).

24 In re Gault, 387 U.S. I (1967).

25 See Morris, supra note 10, at 529-36; Rubin, Prediction of Dangerousness in Mentally Ill Criminals, 27 Arch. Gen. Psychitry 397 (1972) 


\section{The Trial of the Incompetent}

Jackson's invitation to courts to reform civil commitment laws generally should be accepted. Nonetheless, a more direct route to judicial reform of procedures for dealing with permanently incompetent criminal defendants is needed. The risk that civil commitment procedures will be misused in order to protect the community against permanently incompetent criminal defendants would be greatly reduced if the state were permitted to conduct a criminal trial notwithstanding the defendant's permanent incompetency. The state has a legitimate interest in confining persons who have committed criminal acts and it will, if necessary, serve this interest indirectly-and therefore sometimes improperly-through civil commitment proceedings. The defendant has an equally legitimate interest in contesting his "dangerousness" and having its factual basis rigorously determined. Although a permanently incompetent defendant is, by definition, unable fully to enter the contest, this inability is precisely the same whether the state seeks to confine him by criminal or by civil proceedings. Of the two, the criminal trial is more likely to afford the defendant protection against unwarranted confinement.

There are clear and appropriate differences between the purposes of civil and criminal commitment. The premise of civil intervention is a need to prevent infliction of unintended harm to self or others; its promise is that of effective treatment. It is adequately differentiated from criminal commitment only by the prophylactic device of a short time limit, effectively restricting its use to crisis intervention..$^{28}$ As the term of a civil commitment lengthens, however, its claim to a therapeutic purpose loses all plausibility. Community protection becomes its predominant, if not exclusive, purpose, and civil commitment becomes the functional equivalent of criminal commitment. At that point, Baxstrom-Jackson demands that civil and criminal commitment be treated alike-that state confinement of both "ill" and "healthy" people be accomplished under protections of liberty appropriate to the criminal law. In particular, some clear community danger must be proved "beyond a reasonable doubt" to justify long-term confinement of the "ill" as well as the "healthy."27

Unless the use of indeterminate civil commitments is ended, pro-

28 Cf. Katz, The Right to Treatment-An Enchanting Legal Fiction?, 36 U. CHI. L. REv. 755, 773 (1969): "The therapeutic problems created by coerced treatment and by the psychological incapacity of patients to accept, at least initially, an offer of help, suggest the imposition of a 'duty to be treated' only for a limited period of time."

27 See Robinson v. California, 370 U.S. 660 (1962) (criminal confinement for "illness" as such is cruel and unusual punishment). 
cedural tinkering with commitment laws will have little impact on the lot of the mentally ill..$^{28}$ Abandonment of indeterminate civil commitment is, however, unlikely, given its potentially increased utility under Jackson, unless the states are given adequate means by which to differentiate permanently incompetent criminal defendants from all others who might be subject to civil commitment laws. While the fact that an incompetent has been charged with criminal acts does not, of course, mean that he is guilty, it does indicate that there is probable cause to believe his guilt. ${ }^{29}$ States should not, therefore, be denied the power to sort out those incompetent defendants whose release would endanger the community. But they should be required to make this determination in a manner essentially equivalent to that in which "dangerousness" determinations are made regarding all accused criminals. ${ }^{30}$

Use of civil commitment laws to identify the "dangerous" among permanently incompetent defendants would permit states to obscure the criminal analogue by invoking the specter of mental disability. ${ }^{31}$

28 See generally D. Rothman, The Discovery of the Asylum (1971).

29 It may even be that a higher standard of probity is required to support an indictment than the "probable cause" standard required for arrests. See Goldsmith v. United States, 277 F.2d 335, 343 (D.C. Cir. 1960); F. Remington, D. Newman, E. Kimbald, M. Melli \& H. Goldstein, Criminal Justice Administration 432 (1969).

30 Long-term confinement of criminal defendants found "not guilty by reason of insanity" is not inappropriate under the Baxstrom-Jackson principle. Unlike incompetent defendants and persons civilly committed, these defendants have been tried. But under current state practice, acquittal by insanity results in indeterminate commitment, regardless of the maximum sentence that might have been imposed for conviction of the offense charged. See, e.g., Ragsdale v. Overholser, 281 F.2d 943 (D.C. Cir. 1960). While community protection may justify longer confinement of defendants acquitted by reason of insanity than of civil commitees, these defendants do not pose a threat demonstrably greater than do convicted defendants. Baxstrom-Jackson, therefore, requires that confinement of defendants acquitted by reason of insanity be authorized for a period no longer than the term of imprisonment to which defendants convicted of the same offense could be subjected.

Several courts have held that under Baxstrom a defendant found not guilty by reason of insanity may be indeterminately committed only under civil commitment standards and procedures. See Bolton v. Harris, 395 F.2d 642 (D.C. Cir. 1968); People v. Lally, 19 N.Y.2d 27, 224 N.E.2d 87 (1966). But they fail to apply Baxstrom consistently, since they effectively authorize unjustified differences in the terms of confinement of convicted criminals and defendants found not guilty by reason of insanity. At the same time, they apply Baxstrom too rigidly, insofar as they recognize no differences between the civilly committed and defendants acquitted by reason of insanity. The courts' requirement that a separate hearing be conducted, after successful invocation of the insanity defense, to determine whether the defendant remains "dangerously insane" or should be released at once may be desirable, however. It preserves at least the appearance of an internal logic to the insanity defense. For the many anomolies of the insanity defense, see N. Morris, supra note 10.

31 Cf. Goldstein \& Katz, Abolish the 'Insanity Defense'-Why Not? 72 YaLE L.J. 853, 868: "[L]argely unconscious feelings of apprehension, awe, and anger toward the 
It would perpetuate the current regime of long-term compulsory confinement for all of the mentally disabled. To safeguard future reform of civil commitment practice generally, states must, therefore, be permitted to bring permanently incompetent defendants to trial.

Incompetent defendants should sometimes be excused from trial, but the excuse should only be temporary. That, indeed, is the mandate of Jackson - trial should be delayed only long enough to permit a disabled defendant to become more competent. At some point, regardless of the defendant's success in increasing his competence, the criminal charges against him should be disposed of, either by trial or by entry of a nolle prosequi. Incompetency to stand trial would thus be transformed into one of the recognized circumstances for granting trial continuances, and nothing more.

Centuries of common law theology stand in the way of this simple solution. The received doctrine holds that it is unfair and unseemly to subject a mentally disabled person to a criminal trial. ${ }^{32}$ In Pate $v$. Robinson, ${ }^{33}$ the Supreme Court embraced this theology in dicta that "the conviction of an accused person while he is legally incompetent violates due process," essentially because it is inconsistent with the "constitutional right to a fair trial."34

The trial of an incompetent defendant may, indeed, be unfair. Mental disability may substantially diminish a defendant's capacity to testify, to recall exonerating circumstances or identify corroborative witnesses, to aid his attorney before and at the trial, and so forth. In practice, however, it proves to be even more unfair to most, if not all, permanently incompetent defendants to withhold criminal trial. Withholding trial often results in an endless prolongation of the incompetent defendant's accused status, and his virtually automatic civil commitment. This is a cruelly ironic way by which to ensure that the permanently incompetent defendant is treated fairly. Yet it is common practice $^{35}$ and, in the wake of Jackson, it promises to become the customary regime for all permanently incompetent defendants.

The state should not ignore the likelihood that trial disabilities may

'sick; particularly if associated with 'criminality' are hidden by the more acceptable conscious desire to protect the "sick from criminal liability'."

32 See Youtsey v. United States, 97 F. 937 (6th Cir. 1899); United States v. Chisholm, 149 F. 284 (S.D. Ala. 1906); Freeman v. People, 4 Denio (N.Y.) 9, 20 (1847).

33383 U.S. 375 (1966).

34 Id. at $378,385$.

35 See A. MatThews, supra note 2, at 138-40; G. Morris, The Gonfusion of Confinement Syndrome: An Analysis of the Confinement of Mentally Ill Criminals and Ex-Criminals by the Department of Correction of the State of New York, 17 Burfaro L. REv. 651, 657 (1968). 
afflict a permanently incompetent defendant. An incompetent's trial could, however, be conducted under procedural rules that in some measure redress the incapacities suffered by a particular defendant. It could be required that the prosecution afford complete pretrial discovery of its case; ${ }^{36}$ that it meet a particularly heavy burden of proof; ${ }^{37}$ that a corroborating eyewitness establish some or all elements of the alleged offense; ${ }^{38}$ and that special instructions be given to the jury.98 In any case, requirements governing the availability of postconviction relief when new evidence is discovered should be less stringent, allowing relief when the new evidence was unavailable at trial because of the defendant's incompetence.40

The Supreme Court lightly hinted in Jackson that the criminal trial of a permanently incompetent defendant could be permitted:41 "We do not read this Court's previous decisions [citing Pate $v$. Robinson] to preclude the States from allowing, at a minimum, an incompetent defendant to raise certain defenses such as insufficiency of the indictment, or make certain pretrial motions, through counsel." 42 A few state statutes now permit trial of possibly exonerating issues where the in.

36 Cf. F. Remington et al., supra note 29 , at $620-51$.

37 For example, under the present law, a motion for directed acquittal is granted only if the trial judge "reasonably thinks that a reasonable jury could not find guilt proved beyond a reasonable doubt." United States v. Masiello, 235 F.2d 279, 286 (Frank, J., concurring). In the trial of an incompetent, however, it would be appropriate to require that the trial court grant a motion for directed verdict unless it is itself convinced beyond a reasonable doubt that the defendant is guilty.

38 See text and note at note 72 infra.

39 Cf., e.g., text at note 83 infra. Use of rules such as these, invoked only after the state has done its best to help a defendant toward greater trial competency, would satisfy the specific holding of Pate v. Robinson, 383 U.S. 375 (1966), in which the Supreme Court found that the defendant's rights were violated because the state had "ignor[ed] the uncontradicted testimony of [his] history of pronounced irrational behavior" and proceeded to trial without even a hearing on the competency issue, $i d$. at 385-86. Criminal trial of a permanently incompetent defendant would require disavowal only of the broad dicta in Pate, not any repudiation of the ethos of that decision. See text at note 34 supra.

40 The general rule for granting a new trial on the basis of newly discovered evidence requires that the evidence be "material," that it "will probably produce an acquittal," and that "failure to learn of the evidence was not due to the lack of diligence on the part of the defendant." 2 C. Wrigrt, Federal. Practice and Procedure § 557, at 515 (1969). For incompetents, retrial could be granted if the newly discovered evidence "might have led the jury to entertain a reasonable doubt about . . . guilt." Levin v. Katzenbach 363 F.2d 287, 292 (D.C. Cir. 1966) (prosecutor negligently failed to make exculpatory evidence available to defendant at trial). The due diligence requirement has previously been relaxed "in favor of indigent defendants with court-appointed counsel." Amsterdam, Search, Seizure, and Section 2255: A Comment, 112 U. PA. L. Rev. 378, 392 (1964).

41 The Court did not specify any disposition for Theon Jackson, but held, rather, that his commitment for incompetency to stand trial must be ended. 406 U.S. at 738-39. 42406 U.S. at 741 (emphasis added). 
competent defendant's personal participation is not necessary. ${ }^{43}$ Some jurisdictions even permit full-scale trial of the incompetent with the qualification that a guilty verdict must be set aside and the case retried after the defendant has become fully competent. ${ }^{44}$

These special procedures for full-scale or more limited "innocentonly" trials are not, however, important reforms. They address the illogic, tolerated in most states, of precluding an incompetent defendant from exonerating himself even though he has an irrefutable trial defense. The full-scale innocent-only trial does force the prosecutor to offer his entire case for judgment. But by their pretense that only an acquittal is officially recorded, both procedures mask their true import: the defendant is released if found innocent, but incarcerated indefinitely if he is not.

For many, perhaps most, incompetent defendants, a clear verdict of "guilty" would probably be more advantageous than indeterminate incarceration following a "non-innocent" finding. An excellent empirical study by Louis McGarry and others has established the striking degree to which this is so in Massachusetts, ${ }^{45}$ and it is likely that it is so in most states. Hospital authorities are exceedingly reluctant to discharge, or even to authorize brief community leaves for, mental patients confined while criminal charges are outstanding. ${ }^{46}$ In many states,

43 See, e.g., Mont. Rev. Codes ANn. § 95-506(c) (1969); N.Y. Code CrnM. Proc. § 730.60(5) (1971). But see United States v. Barnes, 175 F. Supp. 60 (S.D. Cal. 1959).

44 See Mass. GEN. Laws ANn. ch. 123, \& 17 (1972); [English] Criminal Procedure (Insanity) Act 1964, c. 84, § 4; R. v. Roberts, [1953] 2 All E. R. 340 (Devlin, J.). The expense and possible duplication of effort involved in this procedure has led at least one progressive bar association committee to recommend against adoption of "innocentonly" trials of incompetent defendants. Mental Illness, Due Process and the Criminal Defendant: A Second Report and Additional Recommendations bY the Special Com-

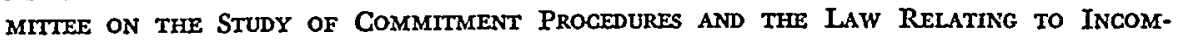
PETENTS OF tHe Association OF THE BAR of THE CITY OF NEW YoRK 115 n.104 (1968) [hereinafter cited as Special Committe Study].

45 McGarry studied two reasonably comparable groups of criminal defendants found incompetent to stand trial; persons in one group had been civilly committed following dismissal of charges and persons in the other had been committed until competent to stand trial on the criminal charges, which remained outstanding. McGarry found, over a seven-year observation period, that the average confinement of those committed as incompetents was sixty-one months while the average hospital stay of those who were civilly committed was only fourteen months. One in six of the incompetent defendants had been returned to the community, but every member of the civilly committed group had been discharged to the community. McGarry \& Bendt, Criminal vs. Civil Commitment of Psychotic Offenders: A Seven-Year Follow-up, 125 AM. J. PsXchiatry 1387 (1969).

46 See Memorandum from William H. Anderson, M.D., Director, Department of Mental Health, State of Michigan, to Superintendents of Hospitals for Mentally IIl, March 14, 1969, at 1-2 (copy on file at The University of Chicago Law Review) (emphasis added):

[N] p patient hospitalized with the legal status of incompetent to stand trial shall 
their release is specifically forbidden ${ }^{47}$ and, in practice, hospital authorities must take the initiative of negotiating with prosecuting officials to dismiss charges. ${ }^{48}$ Even where release is not formally proscribed, the practical obstacles are formidable; only a zealous state hospital administrator will have much success in freeing a patient confined with criminal charges outstanding. ${ }^{49}$

Though Jackson no longer permits indefinite incompetency commitments, the Court has not ruled on whether a state can maintain outstanding criminal charges following civil commitment of an incompetent defendant. ${ }^{50}$ It thus remains possible that the more onerous treatment now accorded incompetents committed with charges outstanding will continue when their commitment is denominated civil. ${ }^{51}$ If, however, the state were given the option to try a permanently

be released on visit, leave of absence or convalescent status, and all indicated reasonable precautions shall be taken to prevent such patients from leaving the hospital without authorization. Patients in this legal classification are not eligible for discharge under any circumstances.

In view of the history of criminal involvement in these cases and the continuing jurisdiction of a criminal court, the avoidance of an unauthorized absence or escape is to be given priority consideration.

47 See, e.g., ALA. CoDE tit. 15, § 426 (1959): "In no event shall such person be set at large so long as such prosecution is pending ...."

48 Local prosecutors are frequently reluctant to dismiss charges, no matter how long the incompetent accused has been confined in the state institution. See A. Matrmews, supra note 2, at 138-40. In a recent habeas corpus proceeding the prosecutor refused to dismiss charges, or to speculate about whether the trial of an eighty-six-year-old defendant, who had been confined as incompetent for almost twenty years, could ever take place. Though key witnesses for the prosecution and defense had died, the state argued that "the question whether the prosecution has evidence on which to go to trial." United States ex rel. von Wolfersdorf v. Johnston, 317 F. Supp. 66, 67 (S.D.N.Y. trial ... ought to be considered 'only *** when and if the relator is able to stand 1970).

49 A study of inmates in Mattewan, the relevant institution in New York, found that in 1965, 19 percent (208) of those confined as incompetent to stand trial had been there for twenty years or more, and 8 percent (89) had been there for thirty years or more. In 1966, the Supreme Court decided Baxstrom, which involved a Mattewan inmate, and under the impetus of that decision, the number of twenty-year men was reduced to sixty-nine, and the number of thirty-year men to twenty-six. SPECial Commrttee Study, supra note 44, at 214-17 (tables 8 \& 9). Based upon their independent examinations, Dr. McGarry and his colleagues found that 33 percent (71) of the men indeterminately committed to Bridgewater as incompetent to stand trial could be immediately returned for criminal trial. The average hospitalization of those who could be returned for trial had lasted four years and three months, while the average hospitalization of those still incompetent to stand trial had lasted fourteen years and nine months. McGarry concluded that the statistics "more than suggest that most of the total population of 219 had been competent for trial early in their hospitalization and that a return for trial at that time would likely have spared them decades of hopeless and regressive institutionalization." McGarry, supra note 2, at 1183 .

50406 U.S. at $739-40$.

51 See Morris, supra note 10, at 524-25; text and note at note 45 stupra. 
incompetent criminal defendant, there would be no justification for invoking civil commitment processes without dismissing the criminal indictment.

Giving the incompetent defendant-rather than the state-the power to choose between criminal trial and civil commitment proceedings would be much less desirable for both the defendant and the state. An incompetent defendant is, at least as much as an ordinary defendant, at the mercy of his attorney's skill and zeal. Like the typical criminal defendant, the typical incompetent relies upon appointed counsel or some form of public defender representation. ${ }^{52}$ Both groups of attorneys are often heavily burdened with work and less than fully skilled in or fully committed to criminal advocacy, particularly when complicated by issues of mental illness. ${ }^{63} \mathrm{~A}$ criminal trial takes time and effort; incompetency commitment and civil commitment proceedings are less time-consuming and easier for all the official participants. The extravagant number of accused misdemeanants who are committed, on their attorney's motions, for incompetency determinations requiring thirty- to ninety-day confinements ${ }^{64}$ is testimony to the casualness with which defendants may be channeled toward commitment and away from trial. In practice, it appears that a permanently incompetent defendant's best interest would almost always be served by permitting the state to proceed to criminal trial. ${ }^{55}$

In addition, the state's legitimate interest in community protection may on occasion require that an incompetent defendant who would otherwise opt for civil commitment proceedings be brought to trial. Indeed, the state's need to resort to criminal trial would be greatest precisely when civil commitment processes are reformed to become sufficiently rigorous in both substantive formulation and administration. A recent Illinois decision and its sequelae in a case "virtually indistinguishable" 58 from Jackson, illustrate this need. An illiterate deaf-

52 See generally Argersinger v. Hamlin, 407 U.S. 25 (1972).

53 See Lewin, supra note 21, at 246: "In most [Michigan incompetency-determination] cases, the defendant did have the assistance of counsel. . . . [T] This assistance could best be described as inept, inadequate, and a travesty of the traditional system of advocacy."

54 Cf. Judicial Conference of the District of Colvumbia Circuit, Report of the Committee on Problems Connected with Mental Examination of the Accused in Criminal Cases, Before Trial 49 (1965): "[I]n the seven-year period fiscal 1956 through fiscal 1962, Saint Elizabeth's Hospital received as incompetent more than twice as many accused misdemeanants (422) as accused felons (194)."

55 There would be some incongruity in a rule that vested the choice between trial and civil commitment proceedings in the incompetent defendant, even if his counsel could be relied upon to choose wisely for him. Cf. Pate v. Robinson, 383 U.S. 375, 384 (1966) (" $\Pi \mathrm{t}$ is contradictory to argue that a defendant may be incompetent, and yet knowingly or intelligently 'waive' his right[s] . . . .").

so Jackson v. Indiana, 406 U.S. 715, 735 (1972). 
mute, indicted for murder, had been committed in 1966 as incompetent to stand trial. As the Jackson Court recounted:

The institution where petitioner was confined had determined, “... that [petitioner] will never acquire the necessary communication skills needed to participate and cooperate in his trial." Petitioner, however, was found to be functioning at a "nearly normal level of performance in areas other than communication." The State contended petitioner should not be released until his competency was restored. The Illinois Supreme Court disagreed. It held:

"This court is of the opinion that this defendant, handicapped as he is and facing an indefinite commitment because of the pending indictment against him, should be given an opportunity to obtain a trial to determine whether or not he is guilty as charged or should be released." [People ex rel. Meyers v. Briggs, 46 Ill. 2d 281, 288, 263 N.E.2d 109, 113 (1970)]. ${ }^{.7}$

Quite possibly the Court was unaware that the Illinois defendant was not in fact brought to trial; in the four years that had passed since his indictment, the state's case had virtually vanished. Because the defendant was "functioning at a nearly normal level . . . " civil commitment proceedings were not instituted either, and the defendant was released. A few months later, he was arrested for the murder of a young woman, accomplished in precisely the same manner and in similar circumstances as had been alleged in the indictment of four years earlier. This time the state proceeded immediately to criminal trial and the defendant was convicted. ${ }^{58}$

As the Illinois case shows not all incompetent criminal defendants are proper candidates for civil commitment. The state's legitimate interest in public safety requires that some incompetent defendants be tried notwithstanding their trial disadvantage. Of all the trial disadvantages under which a defendant may labor, however, present rules make mental disability the only one that permanently disables the state from bringing the defendant to trial no matter how energetically it has tried to remedy his disadvantage. A long delay between the discovery of an offense and its prosecution, or between arrest or indictment and trial may, of course, create a trial disadvantage that bars trial because of limitations statutes or the constitutional guarantee of a speedy trial. ${ }^{59}$ But since state authorities are clearly responsible, by

57 Id. at 735-36.

58 People v. Lang, No. 71-2564 (Cook County, Ill. Crim. Ct., 1971).

59 See Klopfer v. North Carolina, 386 U.S. 213 (1967); Note, The Right to a Speedy Trial, 20 Stan. L. REv. 476, 485 (1968). 
willful acts or omissions, ${ }^{60}$ for the delay that causes the defendant's disadvantage, it roughly accords with justice to bar vindication of the state's interest in community protection.

The conflicting interests of the state and mentally incompetent defendants cannot, however, be reconciled by Solomonic devices: the community's need to identify a harmful actor and protect itself against him is not diminished in urgency or in justice by the fact that he is mentally disabled. Similar interests are reconciled in the several contexts examined below by a device at least as familiar as a statute of limitations.

An accused who is at a trial disadvantage not attributable to unjustified state action may be granted a continuance in order to minimize the obstacle to a fair trial. In these situations, analogous to that created by mental disability, criminal trials are not permanently precluded. Rather, they are properly delayed. When it becomes clear that the trial disadvantage cannot be remedied, criminal trial does take place. There is considerable tension, therefore, between the notion that due process forbids criminal trial of mentally disabled persons and the equal protection principle implicit in the Baxstrom-Jackson inquiry into why the mental disability of some accused or convicted offenders should lead to their being treated differently from others similarly situated.

1. Unavailability of Witnesses. The Sixth Amendment gives a criminal defendant the right "to have compulsory process for obtaining witnesses in his favor." Although the absence of a favorable witness can completely undermine an accused's defense, inability to produce a missing witness does not bar trial. Even further, a defendant is not necessarily granted a trial continuance during which to locate a witness. The customary rule has been stated more narrowly:

When a continuance is sought to obtain witnesses, the accused must show who they are, what their testimony will be, that the testimony will be competent and relevant, that the witnesses can probably be obtained if the continuance is granted, and that due diligence has been used to obtain their attendance on the day set for trial. ${ }^{\text {i }}$

There are two notable differences between the "missing witness"

60 See United States v. Ewell, 383 U.S. 116 (1966); Pollard v. United States, 352 U.S. 361 (1957) (wrongful trial delay must be caused by a "deliberate act of the government," which was both "purposeful" and "oppressive").

01 Leino v. United States, 338 F.2d 154, 156 (10th Cir. 1964). See also C. WrigrT, supra note $40, \S 832$, at 338 . 
disadvantage and the mental disability disadvantage. First, although both involve constitutional guarantees, the trial prejudice caused by absence of a witness must be shown with much more particularity to warrant a short continuance than current "incompetency" practice demands to justify indefinite incarceration. Second, although reasonable efforts to remedy the missing witness disadvantage must be permitted, at some point the government's interest in conducting a criminal trial does take precedence.

2. Defendant's Memory Loss by Amnesia. A defendant's diminished capacity to stand trial because he has amnesia of the events surrounding the alleged crime works the same disability regardless of whether the amnesia is linked to a diagnosed mental illness. ${ }^{62}$ Nevertheless, the incompetency to stand trial doctrine takes account only of amnesia linked to mental illness. This theological rigidity seems required since, if all amnesiacs are found incompetent, then all criminal defendants who, for example, "can't remember where they were on the night of the crime" must also be found incompetent. If, however, permanent memory loss, from whatever cause, were not a permanent bar to trial, courts would no longer need to distinguish among indistinguishable trial disabilities.

The District of Columbia Circuit has recently recognized the anomaly worked by the different treatment of "mentally ill" and other amnesiacs. In Wilson $v$. United States, ${ }^{63}$ the defendant suffered serious head injuries in an automobile accident following a police chase from the site of a bank robbery. The court ruled that the defendant's consequent amnesia of the events of that day was relevant to his competency to stand trial, although not caused by "mental illness." 44 From this premise, Judge Fahy reasoned along traditional lines that the defendant could never be criminally tried since his amnesia, and therefore his incompetency, was permanent.65 The court majority disagreed, holding that "the probability of prejudice, not lack of memory per se, [is] controlling" on the question whether trial can be held. ${ }^{66}$ Because of the defendant's amnesia, the court imposed special procedural rules on any trial-most notably, that the government's case must satisfy an

62 See Regina v. Podola, [1959] 3 All E. R. 418 (ammesia from concussion suffered in attempted escape from scene of crime charged); Note, Amnesia: $A$ Case Study in the Limits of Particular Justice, 71 Yar.e L.J. 109, 116 (1961).

63391 F.2d 460 (D.C. Cir. 1968).

$64 I d$. at 463.

$65 I d$. at 466 (dissenting opinion).

66 Id. at 464 n.4. 
extraordinary burden of proof and that the trial court must make whatever other adjustments are necessary to redress the defendant's disadvantages at trial. ${ }^{.7}$

3. Defendant's Memory Loss by Extensive Time Passage. Passage of time between the date of a crime and trial can drastically reduce an accused's capacity to defend himself, not only because his memory fades but also because witnesses' memories cloud or witnesses become unavailable altogether. Our law has traditionally protected defendants against this trial incapacity in two ways-by statutes of limitations and by the constitutional right to a speedy trial..$^{68}$ As we have noted, these time limits are imposed only as a result of certain government conduct; justifiable government delays, though equally disabling to criminal defendants, do not bar trial. ${ }^{69}$

A recent series of innovative decisions ${ }^{70}$ by the District of Columbia Gircuit offers a close analogy to the changes in incompetency doctrine suggested here. In these cases, the government purposefully delayed the arrest of parties to alleged narcotics sales, and then justified this delay on the ground that its undercover agents must remain anonymous for long periods of time to retain their usefulness, publicly divulging their incriminating information for purposes of a criminal arrest or indictment only at the conclusion of their undercover service. The defendants could hardly be held responsible for these delays.

The court permitted trial of these defendants in some circumstances, notwithstanding the government-created delays. In so holding, the court did not rely solely on the artificial notion that the speedy trial guarantee looks only to the time between arrest or indictment and trial. $^{71}$ It recognized that the delay between the alleged offense and the date of arrest could work fundamental unfairness to a defendant, but required the defendant to make a particularized showing of prejudice in the context of the specific charges and the defendant's spe-

67 Id. at 463-64. The Wilson court went further than here proposed, see text at notes 36-55; it directed the trial court, should the defendant be convicted, to determine whether the defendant's disadvantages were sufficiently overcome and, if not, to set aside the verdict and dismiss the indictment. $I d$.

68 See authorities cited note 59 supra.

69 See cases cited note 60 supra.

70 See, e.g., Woody v. United States, 370 F.2d 214 (D.C. Cir. 1966); Worthy v. United States, 352 F.2d 718 (D.C. Cir. 1965), vacated on other grounds, 384 U.S. 894 (1966); Cannady v. United States, 351 F.2d 817 (D.C. Cir. 1965); Ross v. United States, 349 F.2d 210 (D.C. Cir. 1965).

71 See, e.g., Worthy v. United States, 352 F.2d 718 (D.C. Cir. 1965), vacated on other grounds, 384 U.S. 894 (1966). 
cific needs. The strength of the government's case, and particularly whether the complaining witness's testimony was independently corroborated, was considered a central determinant of the trial's fairness. ${ }^{72}$

4. Defendant's Disruptive Behavior at Trial. One traditional rationale for the incompetency doctrine has been that the trial of a mentally disabled person should not proceed because, though physically present, he is "not there" rationally for purposes of exercising his rights of confrontation and allocution. ${ }^{73}$ The unseemliness of trying an obviously disabled defendant, ${ }^{74}$ whether because he is unattractive or disruptive at trial, is a related explanation. Both of these arguments have been met, however, by the Supreme Court's recent ruling in Illinois $v$. Allen ${ }^{75}$ that, notwithstanding the constitutionally guaranteed right of confrontation, an unruly defendant can be tried while physically restrained or even while absent from the courtroom.

Current events have led the press, and perhaps the Court itself, to view Allen solely as a response to politically-motivated courtroom disruptions. The facts, however, relate the ruling more directly to our immediate subject, the propriety of trying mentally disabled criminal defendants. As Justice Brennan brought out in his concurring opinion, the record suggested that the defendant "was a sick person . . . who may or may not have been insane in the classical sense but who apparently had a diseased mind."76 Allen had been found incompetent to stand trial immediately following his indictment on the charges for which he was ultimately convicted. A year later he was found competent and trial followed, accompanied by the courtroom disruptions for which the Supreme Court approved his binding and gagging. $A l$ len can be read, therefore, as approving special rules to conduct the trial of a plausibly incompetent defendant. ${ }^{77}$ It need hardly be said that a bound and gagged, not to mention absent, defendant is signifi-

72 See Morrison v. United States, 365 F.2d 521, 523 (D.C. Cir. 1965); Bey v. United States, 350 F.2d 467 (D.C. Cir. 1965), cert. denied, 385 U.S. 905 (1966); Ross v. United States, 349 F.2d 210, 215-16 (D.C. Cir. 1965).

73 See Illinois v. Allen, 397 U.S. 337, 338 (1970); Wilson v. United States, 391 F.2d 460 (D.C. Cir. 1968) (dissenting opinion).

74 Cf. Solesbee v. Balkcom, 339 U.S. 9, 22 (1950) (Frankfurter, J., dissenting) (“[T]he heritage of the common law ... deemed it too barbarous to execute a man while insane.").

75397 U.S. 337 (1970).

$76 \mathrm{Id}$. at $356-57$ (Brennan, J., concurring).

77 One court has suggested that a defendant's disruptive behavior at trial may, in itself, require judicial inquiry into his competency to stand trial. See Pouncey v. United States, 349 F.2d 699 (D.C. Cir. 1965). 
cantly disabled in making his defense. The analogy to otherwise disabled-because incompetent-defendants is close. ${ }^{78}$

As these examples suggest, a criminal defendant's interest in having the highest possible degree of "trial competency" need not permanently bar trial. Indeed, in the case of amnesia unrelated to mental illness, it does not bar trial even though the defendant's disadvantage is precisely the same as it would be if mental illness were its cause.

Where the disadvantage is attributable to mental incompetency, courts should be no more hesitant to authorize the use of tranquilizing medications than they must be under Allen to authorize physical restraint. Some jurisdictions have nonetheless applied the rigid rule that use of any tranquilizing drugs by a criminal defendant is itself conclusive evidence of trial incompetency. Since the Cook County, Illinois, Criminal Court embarked on this policy in 1970, the result has been that incompetent defendants are committed to state mental hospitals where medications are administered to reduce the defendants' anxieties so that they can face trial. The defendants are then returned to jail, and, by court rule, psychotropic medication is withdrawn at least seventy-two hours before trial. ${ }^{79}$ Under the pressures of jail and impending trial, without medication, many of these defendants are taken to court highly disturbed, hence unfit for trial, ${ }^{80}$ and therefore recommitted to the state mental hospital, completing the first circle of an absurd merry-go-round. ${ }^{81}$

Use of drugs could, of course, interfere with a defendant's compe-

78 Courts are not averse to trying defendants who are physically disabled. For example, in Redwine v. State, 36 Ala. App. 560, 61 So. 2d 715 (1952), the defendant's arms and legs were fractured at the time of trial; he could hardly gesture very vigorously in his own defense. In Shetsky v. State, 290 P.2d 149 (Okla. Crim. App. 1955), the defendant was tried while on a stretcher, attended by a physician, nurse, and ambulance driver; he may not have regarded himself as entirely present at trial. See also United States v. Knohl, 379 F.2d 427 (2d Cir. 1967).

79 See Notice from Dr. Patrick R. Staunton, Chicago Area Zone Director, Illinois Department of Mental Health, to All Superintendants, Chicago Area Zone, July 8, 1970 (copy on file at The University of Chicago Law Review), relating instructions from Chief Justice Joseph Powers of the Criminal Court of Cook County.

80 See, e.g., People v. Farris, Indictment No. 60-1061 (Gompetency Hearing, Cook County, Ill. Cir. Ct., June 9, 1971).

81 The Illinois Counsel on the Diagnosis and Evaluation of Criminal Defendants' recommendation that the more appropriate rule-that use of tranquilizing or other drugs does not necessarily render a defendant unfit for trial even though such drugs are essential to "insure and maintain his mental fitness"-was not accepted by the legislature. Compare III. Unified Code of Corrections § 510-6(f) (Tent. Draft 1971) with III. Unified Code of Corrections \& 1005-2-1 (1972). See also Hansford v. United States, 365 F.2d 920 (D.C. Cir. 1966); Hayes v. United States, 305 F.2d 540 (8th Cir. 1962); State v. Rand, 49 Ohio Op. 2d I27, 247 N.E.2d 342 (Com. P1. 1969); State v. Arndt, 1 Ore. App. 608, 465 P.2d 486 (1970). 
tency to stand trial, if, for example, the drug's effect were to give him an odd appearance ${ }^{82}$ that might lead a jury to misinterpret his courtroom demeanor: an unperturbed "wooden face" might give a jury the impression that the defendant is a calculating, merciless criminal. ${ }^{83}$ That is not to say, however, that even a defendant drugged into openeyed somnolence should never be brought to trial. Rather, efforts should be made in all cases to avoid trial of a drugged defendant, and trial should go forward with the aid of medication only if it is necessary for the defendant's improved competency. If medication seriously interferes with his trial conduct or appearance, but the defendant is permanently incompetent without such drugs, the trial should be permitted under special rules to mitigate the deleterious aspect of the drug's use. For example, the jury should be given a cautionary instruction at the beginning of trial explaining that the defendant's odd appearance and his nonparticipation at trial is a product of the tranquilizing drugs.

\section{Continuanges and Incompetency: A Recommendation}

Our discussion thus far has concerned procedures appropriate for dealing with permanently incompetent criminal defendants. Whether a particular incompetent defendant is permanently incompetent was given central importance by Jackson: only a defendant whose incompetency is not permanent may be committed for treatment solely because he is incompetent to stand trial. How, then, are courts to determine the permanence of a defendant's incompetency?

We propose two general rules to govern this determination. First, before trial is ever delayed solely on the ground of a defendant's incompetency, a court must specifically find that there is a "substantial probability" that the defendant will be competent to stand trial "within the foreseeable future." Second, no trial may be delayed longer than six months solely because of a defendant's incompetency.

The first of these rules derives directly from the Court's holding in Jackson that preliminary diagnostic commitment of an incompetent defendant "cannot be ... for more than the reasonable period of time necessary to determine whether there is a substantial probability that he will attain [trial competency] in the foreseeable future." 84 The Court thus clearly implied that subsequent commitment, following an

82 See generally F. Redich \& D. Freedman, The Theory and Practice of Psychiatry 370 (1966); L. Goodman \& A. Gilman, The Pharmacological Basis of Therapeutics (3d ed. 1965).

83 See State v. Murphy, 56 Wash. 2d 761, 355 P.2d 323 (1960).

84406 U.S. at 738. 
initial diagnosis, must be grounded on "substantial probability" that the defendant will become competent "within the foreseeable future" 一that is, "soon." 85 On this basis, Theon Jackson's incompetency commitment was wrong from the beginning. As the Court noted, nothing in the record of his initial commitment proceeding suggested "any possibility that Jackson's . . . condition can be remedied at any future time."8s

Under the Jackson Court's demand of a "substantial probability of success," incompetency commitments can probably be justified in practice only if state authorities provide courts with individual treatment plans that specifically set out the particular defendant's treatment needs, the capabilities of state facilities to meet those needs, and the prior experiences with comparably disabled persons upon which the state bases its favorable prognosis for the individual defendant. ${ }^{87} \mathrm{Re}$ quiring some specific justification for the state's prediction that its treatment will help the defendant may appear to be tilting at windmills, ${ }^{88}$ in view of the present, limited capacity to make predictive

85 "Furthermore, even if it is determined that the defendant probably soon will be able to stand trial, his continued commitment must be justified by progress toward that goal." Id. (emphasis added).

$86 \mathrm{Id}$. at 726.

87 To vindicate patients' constitutional rights to treatment, the following requirement was recently imposed upon Alabama state mental institutions:

Each patient shall have an individualized treatment plan ... developed ... no later than five days after the patient's admission. Each individualized treatment plan shall contain:

a. a statement of the nature of the specific problems and specific needs of the patient;

b. a statement of the least restrictive treatment conditions necessary to achieve the purposes of commitment;

c. a description of intermediate and long-range treatment goals, with a projected timetable for their attainment;

d. a statement and rationale for the plan of treatment for achieving these in. termediate and long-range goals;

e. a specification of staff responsibility and a description of proposed staff involvement with the patient in order to attain these treatment goals;

f. criteria for release to less restrictive treatment conditions, and criteria for discharge;

g. a notation of any therapeutic tasks and labor to be performed by the patient .... Wyatt v. Stickney, 344 F. Supp. 373, 384 (M.D. Ala. 1972). An earlier stage of this litigation is reported at $325 \mathrm{~F}$. Supp. 781 (1971).

88 The low state of prediction and treatment skills in psychiatry is no reason for courts to withhold pressures for their improvement. Cf. Bazelon, New Gods for Old: "Efficient" Courts in a Democratic Society, 46 N.Y.U.L. REv. 653, 657 (1971):

If, in response to constant judicial questioning, the official answer is always, "We don't know why we're doing what we're doing," something substantial has been learned. Equally important, there is then simply no reason why courts should accept these official solutions as true and act upon that basis. It is one thing to take judicial action upon the basis of expert knowledge beyond judicial ken. It is quite another to take judicial action on the basis of an expert's conclusion when he himself admits that he doesn't know what he's talking about. But unless the courts ask the necessary question, they can never be sure which situation is which. 
judgments in mental health matters generally. A less demanding showing, however, is unlikely to establish "substantial probability" and likely to degenerate into an empty litany of promises that cannot be kept.

The Supreme Court's directions on the permissible duration of initial diagnostic commitments and any subsequent incompetency commitments are, unfortunately, not explicit. Diagnostic commitment may be for no more than a "reasonable" time, but reasonable in relation to what? The time needed for a diagnosis is largely a function of the state's willingness to commit resources to that purpose. With a suffcient number of psychiatrists and psychologists, diagnosis could usually be performed in a few days and always in the defendant's home community. The courts are not likely to insist on attainment of this ideal, but it would be regrettable if they allowed Jackson's "reasonableness" standard to validate existing practice. Most states presently permit thirty- to ninety-day diagnostic commitments, ${ }^{80}$ often to remotely located state institutions far from the family and community ties that might enable the accused to sustain such equanimity as he can in adversity. The Court should have made clear that constitutional norms demand expedition in diagnosing trial competency, treating those incompetents whose disability is not permanent, and terminating their incompetency commitments. Two constitutional rights are, after all, at stake-the rights to bail and to speedy trial.

In many states, a determination of incompetency makes a defendant automatically ineligible for bail release, ${ }^{90}$ although the Supreme Court long ago held that restrictive bail must be justified, at a court hearing, as "relevant to the purpose of assuring the presence of that defendant" at trial. Denying bail to an incompetent may be justified if his confinement for treatment is clearly necessary to make him competent and thus to "assur[e his] presence at trial." At the same time, however, denial of bail to the many defendants who may be helped toward competency as well, or better, in outpatient facilities, ${ }^{92}$ or for any time longer than is relevant to "the purpose of assuring [their] presence" at trial, violates the constitutional norm. ${ }^{93}$

89 See A. MatThEws, supra note 2, at 81-82. For the procedures typically followed in the psychiatric evaluation, see Judicial Conference of the District of Columbia Circuit, supra note 54 at 29-31 (1966).

90 See, e.g., Ala. Code § 15.426 (1959); ArIz. Crim. P.R. 250(B); Cal. Penal Code $\S 1371$; IND. ANn. STAT. \& 9-1706a (Supp. 1972) (now codified as IND. Code of 1971, § 35-5-3-2); NEv. REv. STAT. § 178.430 (1971).

01 Stack v. Boyle, 342 U.S. 1, 5 (1951).

02 See generally, Chambers, Alternatives to Civil Commitment of the Mentally Ill: Practical Guides and Constitutional Imperatives, 70 Mich. L. Rev. 1107 (1972).

93 Apart from considerations derived directly from the constitutional right to bail, 
In most states, the right to a speedy trial has been considered inapplicable to defendants committed as incompetent, thus permitting indefinite pendency of criminal charges and trial following release from commitment. ${ }^{94} \mathrm{~A}$ few courts have attempted to justify this procedure by arguing that an incompetent defendant "waives" his right to speedy trial when he is committed. ${ }^{95}$ Even though the defendant himself might be incompetent "knowingly and intelligently" to waive the right, ${ }^{96}$ the argument might be plausible-or at least tolerable-if the incompetency commitment benefits the defendant. But the defendant reaps only detriment from any commitment other than a short-term commitment likely to make him more competent for trial. It might also be argued in defense of present practices that the right to speedy trial, abridged only by "purposeful" state delay, ${ }^{97}$ is not abridged where delay is necessitated by a defendant's incompetence. Once an incompetency commitment ceases to have "substantial probability" of making the defendant competent, however, it is quite apparent that continued commitment serves only the state's purpose of keeping the defendant off the streets. Neither theory, therefore, disguises the fact that an incompetency commitment that becomes no more than bare incarceration should not toll the guarantee of a speedy trial.

Consideration of an incompetent defendant's constitutional rights to bail and a speedy trial leads to the conclusion, announced in Jackson, that incompetency commitment can be justified only by a high probability that it will lead to trial "soon." The question still remains, "How soon is soon?" Since the duration of commitment is itself the determi-

some courts have held that the state is constitutionally obliged to provide the least restrictive setting possible for any involuntary treatment, whether accomplished by civil or incompetent criminal defendant commitment procedures. See Covington v. Harris, 419 F.2d 617 (D.C. Cir. 1969); Lake v. Cameron, 364 F.2d 657 (D.C. Cir. 1966); Wyatt v. Stickney, 325 F. Supp. 781 (M.D. Ala. 1971); Chambers, supra note 92, at 1145; of. United States v. Klein, 325 F.2d 283 (2d Cir. I963).

94 See, e.g., ARIz. Crm. P.R. § 250(B); Ind. ANn. Stat. § 9-1706a (Supp. 1972) (now codified as IND. CODE of 1971, \&35-5-3-2) ("[U]pon the return to court of any defendant so committed he or she shall then be placed upon trial for the criminal offense the same as if no delay or postponement has occurred by reason of defendant's insanity."); Mo. Rev. Stat. \$ 552.020 (Supp. 1971); OHo Rev. Code ANN. \& 2945.38 (Page 1954); R.I. GeN. LAws § 26-4.5 (1968); Utah ANn. Code § 77-48-5 (Supp. 1971); Wyo. Stat. ANN. § 7-24I(C) (Supp. 1971). But see In re Harmon, 425 F.2d 916 (Ist Cir. 1970); Williams v. United States, 250 F.2d 19 (D.C. Cir. 1957); United States ex rel. von Wolfersdorf v. Johnston, 317 F. Supp. 66 (S.D.N.X. 1970); United States v. Jackson, 306 F. Supp. 4 (N.D. Cal. 1969). 95 See, e.g., State v. Violett, 79 S.D. 292, 111 N.W.2d 598 (1961); Note, supra note 59, at 480; cf. Commonwealth v. Bruno, 435 Pa. 200, 255 A.2d 519, 522 (1969).

96 Pate v. Robinson, 383 U.S. 375, 384 (1966); see note 55 supra. The speedy trial right is properly deemed to be waived when delay results from defendant's self-interested conduct. See, e.g., Osborne v. United States, 371 F.2d 913, 925-26 (6th Cir. 1967) (repeated motions); United States ex rel. Von Cseh v. Fay, 313 F.2d 620 (2d Cir. 1963).

97 See cases cited note 60 supra. 
nant of whether constitutional rights are violated, it is apparent that "soon" should not be very long at all.

The Jackson Court refused "to prescribe arbitrary time limits" for incompetency commitments "[i]n light of differing state facilities and procedures and a lack of evidence in [the] record." 98 But there is no way to resolve the question of permissible duration other than to impose "arbitrary time limits." The time needed to remedy a defendant's incompetency to stand trial is, to a significant degree, dependent upon the state's willingness to commit treatment resources to that end. While the time required for treatment is not as subject to control as the time needed for diagnosis, it is nonetheless clear that allocative choices in favor of psychiatric treatment resources do have important impact on the length, and even ultimate success, of treatment in a substantial number of cases. ${ }^{99}$ Thus, the Jackson Court's conclusion that time limits for incompetency commitments should not be imposed without greater knowledge of "differing state facilities and procedures" runs backward. Time limits should be imposed in order to dictate the facilities and procedures that the state must make available.

The time limits required need be arbitrary only in the sense that the values at stake are not reconcilable by quantification. A defendant's disadvantages from pretrial delay and incarceration, against which rights of speedy trial and bail would normally protect, can be legion. Conversely, a multitude of disadvantages can arise from the trial of a mentally incompetent defendant. Who can say with certainty when the disadvantages addressed by the speedy trial right-for example, the fact that witnesses may vanish-outweigh the disabilities worked at trial by the defendant's mental incapacities-for example, the fact that his own memory of crucial events is inaccessible?

The Supreme Court has elsewhere accommodated individual constitutional rights to the state's interest in community protection by using arbitrary time scales. The Court has held, for example, that the constitutional right to a jury trial does not apply to offenses punishable by less than six months' imprisonment. ${ }^{100}$ It has permitted criminal contempt proceedings to be conducted without traditional constitu. tional safeguards so long as imprisonment does not exceed six months. ${ }^{101}$ With regard to voting rights, the Court has recently ruled, in effect, that the Constitution prohibits a durational residency require-

98406 U.S. at 738.

99 See, e.g., L. Ullmann, Institution and Outcome: A Comparative Study of PsychiATRIC Hospitals (1967).

100 See Baldwin v. New York, 399 U.S. 66 (1970).

101 Cheff v. Schnackenberg, 384 U.S. 373 (1966). 
ment of more than thirty days; ${ }^{102}$ the particular constitutional right at stake led the Court to mandate a greater than customary allocation of state resources to vindicate the state's legitimate interest in the integrity of election processes. The same kind of mandate should be applied to incompetency commitments.

We urge that the maximum permissible commitment of those found incompetent to stand trial be set at six months. That is a markedly shorter time than that allowed in the few jurisdictions that now effectively limit incompetency commitments. New York's recently enacted maximum commitment for incompetent felony defendants is two-thirds of the maximum sentence that would be permitted following conviction of the offense charged ${ }^{103}$-making law of the premise that permanently incompetent defendants are to be treated as though guilty of the offense charged. Federal practice, which permits incompetency commitments of approximately eighteen months before a defendant must be released from federal custody and the indictment against him dismissed, ${ }^{104}$ reflects the related assumption that any person confined for eighteen months will almost certainly have his confinement continued under state civil commitment laws. ${ }^{105}$ These extensive time limits on their face violate the constitutional rights to bail and speedy trial: "[G]ontinued commitment must be justified by progress toward [the] goal" of trial competency. ${ }^{106}$ Since the constitutionality of an incompetency commitment now depends upon a persuasive showing of a favorable prognosis, years-long confinement is patently absurd.

Confinement for one year's time might have treatment justification in some cases. But, if the central argument of this article is accepted, termination of an incompetency commitment will not necessarily lead to dismissal of the criminal indictment, as it does under current federal and New York practice. If criminal trial is possible following termination of an incompetency commitment, then one year's confinement seems too long. It would be wrong to add a year's delay to the other disadvantages that a permanently incompetent defendant might face

102 Dunn v. Blumstein, 405 U.S. 330 (1972).

103 N.Y. CODE CRIM. PROC. \& 730.50(3) (1971). Incompetent misdemeanor defendants are committed for ninety days "for care and treatment in an appropriate institution;" the court "must dismiss the indictment ..." Id. at \$ 730.50(1).

104 See Drendel v. United States, 403 F.2d 55, 56 (5th Cir. 1968); Cook v. Ciccone, 312 F. Supp. 822, 824 (W.D. Mo. 1970).

105 A committee of the District of Columbia Judicial Conference, for example, recommended a two-year maximum for incompetency commitments essentially on the ground that indefinite hospitalization will most likely follow any two year's incompetency commitment. Judicial Conference of the District of Columabia Circurr, supra note 54, at $133,138-39$.

106 Jackson v. Indiana, 406 U.S. 715, 738 (1972). 
at any criminal trial. Six months is a long period of confinementlong enough, in our judgment, for the state to offer help to an incompetent defendant and long enough for the defendant to learn whether the help offered will do him more good than moving immediately to trial on the criminal charges against him.

Our proposal has two further advantages to recommend it. First, it will help make the initial determination of competency to stand trial more sensible. The present substantive standard for competency is elusive. The Supreme Court has said:

[I]t is not enough for the district judge to find that "the defendant [is] oriented to time and place and [has] some recollection of events," but ... the "test must be whether he has sufficient present ability to consult with his lawyer with a reasonable degree of rational understanding - and whether he has a rational as well as factual understanding of the proceedings against him."107

In practice, it is difficult to draw satisfactory distinctions among the varieties of psychological impairments that can reduce a defendant's ability to consult with his attorney or to understand and participate in his trial. The law has purported to avoid this problem by seeking only reasonable degrees of difference among impairments. ${ }^{108}$ Psychiatrists in court have sought to avoid the problem by restricting incompetency opinions to labelled "psychoses," 109 contrary to court-proclaimed doctrine. Under our proposal the court's ultimate inquiry would be whether any disadvantageous psychological disability exists and whether short-term treatment likely to remedy that disability is available. Distinctions drawn among psychological disabilities in order to justify trial continuance on grounds of incompetency would, therefore, be drawn along functional lines. They would almost necessarily be more rational.

Second, if the consequences of an incompetency finding were simply to delay criminal trial long enough to attempt to make the defendant competent, courts might be more willing to provide treatment opportunities to any defendant whose emotional stability and consequent trial competency could be improved. Similarly, criminal defendants would be able to request treatment without fear of being swept into indeterminate commitment. ${ }^{110}$ Paradoxically, permitting the state to

107 Dusky v. United States, 362 U.S. 402 (1960).

108 See, e.g., Note, Incompetency to Stand Trial, 81 Harv. L. REv. 454, 459 (1967).

109 The essence of the typical colloquy between judge and psychiatrist runs: "Doctor, is he competent?" "Your Honor, he is psychotic." And they pass in the night. See A. Matrhews, supra note 2, at 85-87.

110 See Evans v. Kropp, 254 F. Supp. 218, 222 (E.D. Mich. 1966), which held that an 
try permanently incompetent defendants seems likely to secure to more criminal defendants the due process right to be free from serious psychological impairment at trial.

\section{APPENDIX}

Proposed Rules of Court Governing Trial Continuances for Mental Disability

(1) A motion for trial continuance may be filed by the defendant or by the prosecuting attorney alleging that the defendant's competency to stand trial is impaired by mental disability; that is, that the defendant lacks sufficient present ability to consult with his lawyer with a reasonable degree of rational understanding and/or that he lacks sufficient understanding of the proceedings against him.

(2) Upon the filing of such a motion, or upon the court's independent determination that there is a question regarding the defendant's competency to stand trial, the court shall conduct a hearing. If, at the hearing, the court determines that there is sufficient reason to believe that further examination of the defendant by licensed psychiatrists is necessary to determine the defendant's trial competency and his prognosis for greater competency, the court may adjourn the hearing for this purpose for a period of no more than three weeks.

(3) The court shall determine, at the hearing if adjournment is unnecessary, or at a subsequent hearing no more than three weeks after the initial hearing if adjournment was necessary, (a) whether the defendant is incompetent to stand trial because of mental disability and, if so, (b) whether there is substantial probability that the defendant will become competent to stand trial within six months. If the court finds that psychotherapy is required to remedy the defendant's disability, the court shall determine whether an adequate individual plan for the defendant's treatment has been prepared. An adequate plan will specify the program and facilities available for treatment of the defendant and the prior treatment experiences with comparably disabled persons upon which is based the claim of a substantial probability that the defendant will become competent to stand trial within six months.

attorney's "failure to inform the court of his client's mental condition [suggesting incompetency] deprived [the defendant] of the effective assistance of counsel ... ." The attorney had explained that "in his judgment, his client would be far better off in a state prison from which he would be eligible for parole in ten years than he would in the state hospital for the criminally insane .... [The hospital's facilities] were so inadequate ... that commitment would result in permanent confinement in that institution." 
(4) If the court makes affirmative determinations under sections (3) (a) and (3)(b), the court shall grant a trial continuance of no more than three months. If the defendant requires psychotherapy to remedy his disability but is unable to afford such treatment from his own resources, the court shall order that the state provide psychotherapy services to the defendant on an out-patient basis unless it is clearly necessary that treatment be provided on an in-patient basis to make him competent. If in-patient treatment is clearly necessary, the court may order the defendant confined for psychotherapy in an appropriate state facility.

(5) No more than three months following the grant of the trial continuance authorized by section (4), the court shall conduct a hearing to determine (a) whether the defendant remains incompetent to stand trial because of mental disability and, if so, (b) whether, on the basis of the defendant's progress toward remedying his disability, there is a substantial probability that the defendant will become competent to stand trial within three months. If the court makes affirmative determinations under subsections (a) and (b) of this section, the court may grant a further trial continuance for no more than three months. The court may order, or continue its previous order, that the defendant be confined for psychotherapy in an appropriate state facility as provided in section (4).

(6) A motion for trial continuance shall not be granted solely because tranquilizing drugs or other medications have been or are being administered to the defendant under medical direction, unless the court finds that there is substantial probability that the defendant will not require the drugs or medication to be competent for trial within the appropriate time limit prescribed by section (3) or (5).

(7) If, under the procedures set out in sections (3) or (5), the court determines that a defendant is incompetent to stand trial because of mental disability but that there is no substantial probability that such incompetency will be remedied within the appropriate time limit, or that such incompetency has not been remedied within the time- prescribed by section (5), the court shall grant no trial continuance on the ground of the defendant's incompetency. If the prosecuting attorney indicates an intention to bring the defendant to trial, the court shall determine at a pretrial hearing whether fundamental fairness to the defendant requires that special trial or pretrial procedures be used in order to redress his disabilities. The court may prescribe any or all of the special pretrial and trial procedures set out below, or such other procedures as it deems necessary:

(a) Prior to trial, the court shall review all the evidence that the 
prosecution intends to offer at trial and shall order pretrial disclosure of evidence that would materially assist the defendant in overcoming the disabilities under which he labors. Disclosure of evidence that may endanger the lives of witnesses, or in any way promote substantial injustice, shall not be ordered;

(b) On motion for directed verdict, either before or after jury deliberation, the court shall demand from the prosecution a higher burden of proof than would obtain in an ordinary criminal prosecution, and the court shall insist on extensive corroboration of the prosecution's case with respect to issues on which the defendant is likely to be prevented by his disability from effective rebuttal;

(c) If the trial is before a jury, the court shall instruct the jury that in weighing the evidence against the defendant, it should take into account, in the defendant's favor, the disabilities under which he went to trial. If trial is before the judge sitting alone, he shall take account of those disabilities.

(8) Any conviction shall be set aside if evidence that was not available for trial because of the defendant's incompetence subsequently becomes available and might have led at trial to a reasonable doubt regarding the defendant's guilt. 